Families, Relationships and Societies $\cdot$ vol $x \cdot$ no $x \cdot x x-x x \cdot$ CPolicy Press $\cdot 2018$

ISSN 2046 7435 •ISSN 2046 7466 • https://doi.org/10.1332/204674318X15233476441573

Accepted for publication 21 March 2018 • First published online 18 May 2018

This article is distributed under the terms of the Creative Commons

Attribution-NonCommercial 4.0 license (http://creativecommons.org/

licenses/by-nc/4.0/) which permits adaptation, alteration, reproduction and distribution for non-commercial use, without further permission provided the original work is attributed. The derivative works do not need to be licensed on the same terms.

\title{
article
}

\section{Migrant mothers: Performing kin work and belonging across private and public boundaries}

\author{
Tracey Reynolds, ${ }^{1}$ t.a.reynolds@greenwich.ac.uk \\ University of Greenwich, London, UK \\ Umut Erel, umut.erel@open.ac.uk \\ Erene Kaptani, erene.kaptani@open.ac.uk \\ Open University, UK
}

\begin{abstract}
This article explores how migrant mothering kin work challenges private and public boundaries, giving rise to new conceptions and practices of citizenship. We highlight the potential of participatory theatre methods - specifically, forum theatre and Playback - for understanding the relationship between mothering, ethnic belonging and citizenship. We also assess the significance of migrant women's kin work within their families and communities for re-framing notions of citizenship (Erel et al, 2017a, 2018). Our analysis gives particular focus to two scenes developed as part of the participatory theatre project that took place with a group of ethnically and racially diverse mothers in East London. The first scene, entitled 'Where is my food?', draws attention to the mothers' kin work and reproductive labour operating at the boundaries of the public/private dichotomy, and also highlights gendered household dynamics. The second scene, entitled 'At the community centre', examines everyday encounters at the centre, and how 'cultural work', which is pivotal to the mothers' kin work, informs intergenerational relations. The article argues for a more embodied understanding of citizenship in order to broaden understanding of migrant mothers' kin work in making new citizens.
\end{abstract}

key words migrant mothers $\cdot$ kin work $\cdot$ citizenship $\cdot$ ethnicity $\cdot$ participatory theatre

\section{Introduction}

This article explores how migrant mothering kin work challenges private/public boundaries, and this gives rise to new conceptions and practices of citizenship. We highlight the potential of participatory theatre methods - specifically, forum theatre Playback - for understanding the relationship between mothering, ethnic belonging and citizenship. The analysis is influenced by Isin's (2008) concept of 'enacting citizenship' to argue that citizenship is about more than claims to formal rights and 
duties. Instead, our notion of citizenship takes into account migrant mothers' social, cultural and economic contribution to local, national and transnational fields through their kin work and family practices. Importantly, this study takes the approach that migrant mothers' caring work and practices within the intimate sphere of kin (family and friends) re-frames notions of citizenship (Erel et al, 2018). It disrupts dominant narratives of citizenship, which see their subjects as members of the nation state (Erel et al, 2017a).

Migrant mothering also disrupts the logic of public debates concerning what it means to be a 'good citizen' and the boundaries of who may be performing citizenship. This work is both timely and significant in challenging public and media debates that oftentimes position racialised migrant women and their children as the "enemy within borders' (Redclift, 2014). In the UK 'visible minorities' families from diverse ethnic and racial origins are cast as a hostile threat to the nation. In media debates migrant and minority ethnic families are typically associated with violent extremism, for example, Muslim families (Joppke, 2009); exploiting and 'cheating' the state welfare system, for example,African families (Aspinall and Chinoyua, 2016); and in engaging with dysfunctional family patterns that result in violent and criminal activities, for example, Caribbean families (Reynolds, 2005). As outlined in the Casey Review (2016) into social integration, these negative stereotypical images reinforce the view that migrant families do not fully integrate into British society. Moreover, their supposed failure to fully adhere to British cultural values is seen as threatening the security and wellbeing of the nation. These stereotypes create a barrier to migrant and minority ethnic families claiming full rights and entitlements as citizens, or indeed, being seen as rightfully embodying a subjectivity as citizens (Afshar, 2012; Diehl et al, 2009; Erel at al, 2017b).

Our discussion begins by establishing the connections between the theoretical and methodological approach adopted. We highlight the principles of participatory action research, and within this, the main method of participatory theatre that we used in our study. Participatory theatre as used in this study highlighted the ways in which migrant mothers, through their embodied performance, make citizenship claims: this disrupts the normative discourses around citizenship. Their kin work also disrupts normative notions of citizenship.

The next section contextualises the concept of kin work and citizenship within broader constructions of racialised motherhood. We outline how kin work goes beyond privatised notions of caring for one's family, and there is a blurring of the public and private spheres (Hill Collins, 1990; Reynolds, 2003). As racialised and gendered bodies, the migrant mothers, and the kin work they practice, are subject to racialised gendered inequality. Thus, we explore in our analysis how challenging and responding to (perceptions of) racialised encounters represents exemplars of enacting citizenship. Our analysis particularly focuses on two scenes with a group of ethnically and racially diverse mothers. These scenes were developed as part of the participatory theatre project that took place with these women in East London. The first scene, entitled, 'Where is my food?', draws attention to the mothers' kin work operating at the boundaries of the public/private dichotomy, and also highlights racialised gendered household dynamics. The second scene, entitled 'At the community centre', examines everyday encounters at the centre, and how their embodied status as citizens creates for the migrant mothers new cultural forms of intergenerational, care and kin work, 
which take place in local and transnational contexts (see Baldassar and Merla, 2013; Kofman and Raghuram, 2015).

\section{The study}

The project draws on findings from the Arts Humanities and Research Council (AHRC) funded study 'Migrant mothers caring for the future: Creative interventions into making new citizens' (AH/K00591X/1).As part of the study we conducted threehour weekly participatory theatre workshop sessions. These took place with a group of migrant mothers in East London over a period of seven months (February-August 2014). The workshops combined 'Playback' technique (Fox, 1994) and Forum Theatre as part of Boal's Theatre of the oppressed (Boal, 1979). In terms of Playback, this involved the migrant mothers (also referred to as the participants) sharing individual stories about their everyday encounters including their kin work and caring relationships, experiences of racism and access to health and social welfare services. These stories were then acted out by professional actors, re-telling and re-playing their stories back to the women.

According to Kaptani and Yuval-Davis (2008), Playback theatre creates more reflexive distance than is possible in everyday life, allowing participants to see themselves and their interactions with others in a new way. Playback requires relationships of trust and reciprocity in sharing experiences. It produces meaning by building a triangular conversation between actors, individual tellers and the group of participants. Narratives of individual tellers often relate to each other, elaborating on a particular theme, perhaps refining particular themes, perhaps showcasing alternative or contradicting experiences (Kaptani and Yuval-Davies, 2008).

In the workshops, forum theatre followed on from the Playback scenes. The director and activist Augusto Boal (1979) developed Forum Theatre as part of the Theatre of the oppressed. The framework and set of techniques is based on the principles of collective empowerment and emancipation. Boal termed the participating audience members spect-actors, as the process aims to overcome the boundary between passive spectators and actors, allowing participants to practice elements of both roles (spectators and actors) simultaneously. Forum Theatre enables participants to become actively involved in using the theatre as a rehearsal for change in the social world. Participants construct dramatic scenes of their choice based on their personal experiences, and then show the scene to the other participants, who intervene by taking the place of the protagonist and develop strategies for changing the course of action. This allows participants to try out multiple possibilities for social action, and helps to reflect on how individual and collective experiences relate to each other (Erel et al, 2017a).

During these sessions, the migrant mothers put themselves forward to act out particular experiences of social problems or dilemmas they had experienced. Other mothers (participants) stepped into the scene in order to intervene in the scene. They did so by embodying the particular scene by taking the role of the protagonist (the mother), and attempting to change the course of action and create a more desirable outcome. As a result of participants intervening in the performance to change the course of events, forum theatre becomes not only a critical site of negotiation, but also a site of collective mobilisation and empowerment for migrant communities encountering marginalisation and inequalities across many multicultural European nations (Reynolds and Erel, 2016). 
Participatory theatre methods therefore develop a new methodological model and approach to understanding acts of citizenship. Migrant mothers, as a result of their family and community practices, are able to claim full and legitimated citizenship rights (Pakulski, 1999; Ryan andVacchelli, 2013). In our study, participatory theatre, as a social intervention tool, stimulates the mothers' creativity and thinking to reflect on changes to and within family and community relationships. The mothers' performances and participation in the workshops showed them to be claims-making citizens who were able to clearly articulate through their performances their understanding of their rights and responsibilities to family, community and nation state. They also negotiate and contest hegemonic citizenship discourses, which we describe later in this article. The methods of participatory theatre provide a creative space and collective platform for the migrant mothers' voices, stories and performances to take centre stage. These women's voices are usually marginalised in society (Erel et al, 2017b). Participatory theatre methods are congruent with the principles of participatory action research and social justice (O'Neill and Hubbard, 2010), which recognises the importance of valuing all voices (O'Neill, 2017). It adopts a grassroots and 'bottom up approach in generating new knowledge, which is transformatory and interventionist in its approach' (Erel at al, 2017a).

The theatre workshops were led by a facilitator and co-author of the article, Erene Kaptani, who is trained in dramatherapy and social research. Professional actors and musicians also assisted with these sessions. A total of 20 migrant women living in Hackney, East London were recruited through the networks of a carers' group using non-purposive sampling methods. All of these mothers had school-age children. They came from ethnically and racially diverse backgrounds, including Somali, Nigerian, Polish, Lithuanian, Turkish, Kurdish, Congolese women, and had migration trajectories that included family migration and labour migration. During the workshops the mothers also developed a short theatre performance piece that was based on movement and dance. The scenes were presented to social researchers and academics at an end-of-project conference (these can be accessed on the project website, at www.open.ac.uk/socialsciences/migrant-mothers/). ${ }^{2}$

Working with a participatory theatre researcher who is trained in dramatherapy ensured that the participants could perform with their bodies and voices particular scenes that were meaningful in their kin work. Kaptani (forthcoming) argues that theatre processes involve sharing and being allowed to 'mess about' through movement. This offers migrant groups an alternative way - beyond writing and speaking - to communicate their experiences. Oftentimes interview-based forms of research work reproduce institutional practices of social exclusion (Kaptani, forthcoming). This was particularly evident for our group of migrant mothers who were from lowincome working-class backgrounds. Almost all of the mothers lacked any recognised educational qualifications, and their spoken and written English language competences were limited. Therefore, the creative and embodied ways in which the participants used movement, their bodies and actions to communicate their experiences allowed them to enact citizenship. These women became active agents, rather than passive recipients, in making claims of their bodies to improvise and find 'solutions' to the challenges and problems they encountered in their everyday lives. The mothers' narratives about their intimate and family relations are brought from the private sphere into the public realm through their theatre performances during the workshops, blurring the distinction between public and private boundaries. 
The workshops were supplemented by individual in-depth interviews with the mothers. These interviews explored their feelings about participating in the workshops, as well their experiences of mothering and motherhood. Themes included: motherchild relationships, access to health and welfare services, family migration, and what it means to be a migrant mother in British society. The mothers also reflected on the policy changes they would like to see. This produced substantial narratives for each of the participants. Grounded in a constructivist ontology (Denzin and Lincoln, 2005), thematic analysis was used to identify memorable and significant events and analyse differences and similarities of experience across all of the participants. Working with the mothers to co-produce knowledge on family, kin work and citizenship, we set out to challenge traditional discourses around migrant mothering that typically situate them as unwilling or unable to integrate into UK society (Casey, 2016). The participatory methods of forum theatre and Playback helped the migrant mothers to articulate the ways in which they actively create new forms of citizenship through their cultural practices, and kin work. The dramatised illustrative moments they produced highlighted and generated the integrative components of macro, meso and micro everyday interactions in these women's lives, discussed later in the analysis (Lutz, 2010; Yuval-Davis, 2011).

\section{Negotiating public discourses of motherhood, kin work and citizenship}

The substantial body of anthropological literature on kinship has long emphasised the importance of kin work for the maintenance of kinship ties (see di Leonardo, 1984, 1992; Alber and Drotbohm, 2016; Dossa and Coe, 2017). For instance, Povinelli's (2006) analysis of kin work considers normative ideas around love and intimacy in the period of European colonialism and Empire. She theorises that liberal governance operates through discourses of individual agency and social constraint, the latter determined by complex and multifaceted modes of relatedness and sociality organised along kinship ties. During the 1980s anthropologist Micaela di Leonardo (1984) popularised the notion of kin-keeping as work, highlighting the importance of women's role in using kin work to cross public and private boundaries. The study by Dossa and Coe (2017) into transnational ageing in a Canadian context similarly highlights the public performance of private kin work by elderly Muslim migrant women in an institutional setting (palliative hospital) as a way of opening up dialogue about differing cultural values and practices held about death and dying by Muslim patients and their non-Muslim palliative care professionals and workers.

The link between 'race', racialisation and motherhood encourages particular kinds of mothering work and kin work practices that extend beyond the private realm (Stack, 1981; Hill Collins, 1994; Stack and Burton, 1994). This link suggests kin work encapsulates a concept that is much broader than paid work, domestic work and childcare. As Black feminist scholar, Patricia Hill Collins (1994: 48) observes, inherent tensions exist for racialised and ethnicised mothers in raising children, especially in Western societies such as the UK, that seek to denigrate them. The mothering work and practices these mothers engage in reflect 'the dialectical nature of power and powerlessness in structuring mothering patterns and the significance of self-definition in constructing individual and collective racial identity' (1994: 49). Other feminist scholars have utilised a framework of kin work to reflect on the collective labour of 
gendered family-centred networks that sustain intergenerational relations (Doucet, 2009) (which also include transnational care responsibilities) across households (Zontini, 2004; Baldassar and Merla, 2013).

As the above argument suggests, kin work goes beyond privatised notions of caring for one's family, and involves community development that takes place in the public domain. Black and racialised migrant mothers, for instance, recognise that their kin work encompasses particular types of work around identity formation and cultural work. The empowerment of self and children are critical components of political resistance to racial oppression in society (Reynolds, 2005; Gedalof, 2009; Kershaw, 2010). Consequently, the caring activities and collective labour involve racialised mothers encouraging their children to develop a positive sense of self, which in turn provide their children with the skills and resources that allow them to resist experience of racism, while also encouraging them to 'fit in' within this system (Erel at al, 2018). Many Black and racialised migrant women are actively engaged in caring for children and young people through their community and voluntary work (Sudbury, 1998; Dominelli, 2006). The desire to improve migrant children's educational outcomes and economic chances similarly underpin these women's engagement in voluntary work and as 'community workers' or 'community mothers' (Mirza and Reay, 2000; Reynolds 2003). The cultural resources used in racialised and migrant women's mothering practices to foster self-esteem and confidence in their children constitutes community activism founded on political and social solidarity (Gedalof, 2009; Ryan and Vacchelli, 2013).

In an increasingly globalised world, migrant women are focused on family and community survival (Kofman, 2013). In this context, the kin work these mothers engage in is about ensuring the physical survival of their children and family (Lonergan, 2015).According to Baldassar and Merla (2013), however, this goes beyond the focus on mother-child relationships to encompass care across generations and genders, and between home and host countries. In a very practical sense this reveals itself in migrant women disproportionately taking on low-paid, low-status, physical demanding, oftentimes illegal and precarious paid work in order to circulate care for family between developing nations (for example,Africa, Caribbean, South Asia, among others) and the wealthier nations (in, for example, North America, Northern Europe and Australia) for their family (Baldassar and Merla, 2013; Reynolds and Zontini, 2014). Maria Amigo's study (2012: 62), for example, highlights how professional and skilled migrants from Latin American territories migrate to Australia to ensure a more promising environment and future for themselves and for their children. In an ideological sense, migrant women's mothering is about establishing the skills, strategies and resources for their children, families and communities to survive and negotiate systems and structures of racialised oppression (Reynolds, 2005; Erel, 2011; Erel and Reynolds, 2014).

Our study extends and builds on this notion of kin work, refracting it through the analytic framework of citizenship.T.H. Marshall (1953) proposed that citizenship has developed in steps from first, judicial rights, protecting citizens from arbitrary state violence, to second, political rights, such as voting rights, and then finally, leading social rights, providing social security and solidarity between citizens in a welfare state. Feminist scholarship, including the earlier work of Sylvia Walby (1994), emerged to critique this perspective of citizenship rights as progressing sequentially. This work pointed out that such an account of citizenship takes male, White experiences as 
normative, and does not pay attention to the effects of hegemonic conceptions of society as structured by a public/private divide. Protection from arbitrary violence, for example, has not been realised in substantive form for many women who are subjected to domestic violence. One of the reasons for this is the assumption that what happens in the home pertains to the private realm, which, in liberal accounts of citizenship, is considered a safe haven from state intrusion. Yet this conception of the home as private sphere misrepresents the home and intimate sphere as one that is free from politics, hierarchies and power relations (Anthias and Yuval-Davis, 1992). Crucially, as suggested by the work of black feminist scholars, this ignores how intersections of gender, class, race and migration status are closely intertwined in constructing notions of the public/private divide (see Phoenix and Pattynama, 2006; Yuval-Davis, 2006).

According to Lutz (2010:36), this operates for migrant women at intersecting macro, meso and micro levels. At the macro level they are concentrated in low-pay and status domestic work (for example, caring for children or sick/elderly adults or cleaners). The meso level involves the redistribution of migrant workers' own domestic work in the private/intimate spheres, which is typically performed by other female relatives such as the grandmother, aunts and so on. It is at the micro level where migrant women's individual practices, identities and positions come to the fore (Lutz, 2010: 36). The concept of kin work also contests the public/private dichotomy that separates out and distinguishes work performed in family/household from paid work performed in the labour market. As Lutz (2016) points out, many racialised and migrant women work in other people's homes as domestic workers but also undertake paid work in their own homes - as part of family businesses and, more recently, undertaking more highly skilled jobs in the home (for example, as teleworkers, consultants or freelancers). Therefore, the physical location of the workplace and home should not divert attention from migrant women's economic contribution to society.

\section{Public/private boundaries of citizenship}

The focus on kin work in 'reframing migrant mothers' citizenship (Erel, 2011) raises the question, to what extent citizenship is embodied? Bacchi and Beasley (2002)'s study critiques the limited attention given to embodiment in feminist theorising around citizenship, particularly the way in which women's bodies are conceived by policy discourses in terms of ownership, control, rights and protections. So, for example, the normative depiction of victimhood is commonly associated with migrant women. Dustin and Phillips (2008) make a similar argument by charting the shift in the UK's policy focus on migrant women away from a cursory endorsement of multiculturalism to a growing preoccupation with the abuses committed within migrant communities against women (for example, genitalia mutilation, sexual trafficking, honour killings, forced marriages). Underpinning this construction, as Diehl at al (2009) argue, is that these women are ill equipped to deal with Western norms of gender equality and citizenship entitlements. It then becomes the responsibility of other (White,Western, middle-class) women to speak for and reclaim control and rights over these migrant women bodies. Underpinning this assumption is the idea that that migrant women lack the necessary knowledge and confidence to speak on their own behalf.

The notion of embodied citizenship provides a useful starting point for our analysis because it highlights our embodied existence. It connects with the methodological approach of participatory theatre discussed earlier, particularly because embodied 
citizenship emphasises the social relations around movement, communication, touch and sensory materiality (Erel at al,2017a). Individuals are able to listen to the kinds of knowledge the body offers. This performative way of articulating their knowledge through theatre helps to place migrant women's subjectivity as political, providing a precondition for enacting citizenship (Erel et al, 2017a). In policy terms, the state empowers and also erodes citizenship. However, it is our bodies that determine the spaces we can or cannot enter; our gendered and racialised bodies can shed light on who has control (or lack thereof) of public space. Our bodies can similarly determine the type of public and social welfare resources individuals from different groups have access to and the ways they are allowed to access this (Lister, 2003). This raises further questions about what shape and form bodies of 'full' or 'good' citizen subject are supposed to take. By understanding the women as embodied subjects of citizenship who draw on their kin work to establish claims of rights, belonging and participation, our analysis can disrupt and problematise normative understanding of citizenship models.

An alternative conception of migrant women associates them with being objects of political control (Lister, 2008). This discourse bring to the fore questions concerning migrant women's rights and responsibilities in raising 'good citizens' and through their parenting practices and family values, safeguarding cultural and social cohesion (Erel, 2013). According to Lonergan (2015: 124), since 2010 there has been a period of economic austerity that has resulted in a series of cuts to public and welfare spending. Also within this period, successive Coalition and Conservative governments have had a vested interest in reproducing constructions of the 'good' versus 'bad' citizen. Migrant and racialised mothers are often positioned as the 'bad' citizen. They are regarded as 'undeserving' recipients of social citizenship, and disengaged with citizenship other than to draw on social, health and other public services. In contrast White, and particularly middle-class, mothers are positioned as the 'good' citizen. They are regarded as deserving beneficiaries of social citizenship because they contribute to services and engage with citizenship by acting as 'full members' of society.

Our analysis challenges the positionality of migrant mothers as 'bad' citizens. Our findings highlight that migrant women's mothering constitutes engagement with citizenship practices. For instance, these women are creating new ways of being citizens by bringing up children who feel that they belong to both the UK and the mothers' home countries (Erel et al, 2018). In this sense, therefore, migrant mothers are performing 'acts of citizenship' that challenge hegemonic forms, subjectivities and habits of what it means to be a good citizen (Isin, 2008). By taking seriously the ways in which migrant mothers destabilise normative understanding of the public-private boundary, we are able to develop more complex notions of how kin work constitutes an important element of citizenship engagement.

The mothers in our study expressed awareness of the public anxiety and racial stereotyping concerning their kin work. As mentioned earlier, public policy has fuelled anxiety about black and migrant families as producing 'feral youths' running wild on the streets, home-grown jihadist terrorists, and encouraging the 'wrong type' of integration within ethnic communities that discourages full citizenship and integration into societal norms and values (Erel and Reynolds, 2014). This depiction and characterisation of 'problem mothering' who, through their deficit kin work reproduce 'problem citizens', are sometimes explicitly racialised (for example, irresponsible black lone mothers producing rioting youths), but in most cases, they 
tend to be implicitly racialised (Lewis, 2000, 2004). There was recognition by some mothers that as racialised subjects they would not be seen as British, and nor would their contribution to British society, through their kin work, be fully valued. This created contradictory and conflicting meanings with being associated as British and whether their children should accept or reject claims of British citizenship.

Contradictions around claiming or rejecting a British ethnic label have been explored at length in various studies on migrant communities (see Nandi and Platt, 2015; Okolosie et al, 2015). However, at this juncture this feeling of ambivalence concerning ethnic identification must be understood within the broader structural context of racial exclusion, and experiences of racism and racial inequality experienced by migrant communities (Afshar, 2012). Outlined below, the mothers describe their direct experience of being racially discriminated against as part of an everyday encounter:

Interviewer: 'Have you been racially discriminated here [in the UK]?'

Judyta: 'Yes. Yes, many times. It happens to everyone.... If they hear my English they treat me differently. It happened to me because I am from Eastern Europe. Because they see me as not even as [a] second-class citizen.... I came to work here; I pay my taxes, and make me feel [showed with a gesture, like she is no one]. In services like the HMRC [Her Majesty Revenue \& Customs] office they are so rude to me on the phone.'

In the above example, Judyta, a migrant mother of Lithuanian background, describes examples of encounters with racism. She highlights that one of consequences of having a racialised (that is, Eastern European) identity is that she is ascribed a 'noncitizen' status. Judyta is denied full access to social citizenship despite contributing towards the UK economy through full labour market participation, like many other migrant mothers. Our data indicates that the mothers understood both the overt and the more 'covert', subtle forms of racial discrimination. Judyta's comment, 'they are so rude to me on the phone', reveals the way in which these racist encounters present as everyday racial acts of micro-aggression in the public domain. Rudeness and hostility at the hands of members of the public (including other minority groups) and when dealing with health and social care professionals was an experience shared by many mothers in our study. The participants in this study expressed feeling routinely denied recognition as equal participants in their encounters with state and other institutions.

The study yielded rich insight into the way that interlocking structures of race and gender, alongside class, move the women's kin work beyond dichotomised notions of the public (male) and private (female) sphere of the family, challenging dichotomised gendered roles (Anthias and Yuval-Davis, 1992). In the scene entitled 'Where is my food', we explored this gendered dynamic. The theatre facilitator showed a scene developed in previous work with migrant families (see www.open. ac.uk/socialsciences/migrant-mothers/participatory-theatre/), which became the starting point for participants to intervene and change the course of events. The scene is set in the family home and focuses on an argument between the 'wife', who is attending English language classes, and her 'husband', who is challenging her continued attendance of these classes, arguing that she should be looking after the children and him instead. The husband is demanding 'Where is my food?' and the 
participants take it in turn to step into the scene as the wife to engage with various strategies - including being combative, cajoling or providing reasoned arguments - in order to convince the husband that she should be allowed to continue her English language classes. In this Forum Theatre scene, we tested out a range of strategies to bring about the desired outcome, for the husband to agree to the wife attending the English language classes. We were able to observe after each intervention what was happening between the husband and wife.This represented an example of embodied citizenship in action because the dialogue that emerged out of the scenes between the husband and wife brought the migrant mothers into a dynamic communication process, whereby they are able, through performance movement and improvisation, to create different solutions.

During this scene we also explored conflict and tensions within spousal relationships arising from the experience of migration to a new country. The difficulties of adapting to a new language environment, navigating the challenges of bringing up children in an unfamiliar environment and also being confronted with difficult access to the labour market, where many migrants face the devaluation of their skills and work experience from their home country, as well as racism, are all factors setting the context for this scene (Lonergan, 2015). Migration requires an adjustment to new ways of doing things, and therefore the work of establishing a stable home life for themselves and their families constitutes one of the important ways in which migrant mothers enable their families and themselves to participate in wider society (Gedalof, 2009).

The participants' interventions generated awareness of how the mother's kin work might challenge social constructions of work and family as separate spheres by equipping family members, in this scene, the husband, with the resources and skills (for example, English language skills) to eventually improve the family's education and future career prospects. As a social intervention tool, forum theatre helped the mothers to stimulate their creativity and thinking in contesting the place between public/private and between the oppressed and the oppressor. In particular, this dialogue also generated valuable insight around migrant mothers who constituted themselves as citizen subjects through their kin work. It also legitimated knowledge of these mothers concerning the importance of paid work and unpaid domestic activities in contributing to the family household. Such an analysis is important because their subordinate location in society, at the juncture of their gender, racialised and migrant status, makes them especially vulnerable to their contribution to the family and economy not being recognised as important (Bassell and Akwugo, 2017). This scene, we suggest, empowered the mothers by establishing a creative and equalising space for them to reflect on and negotiate patriarchal structures and power relationships that inform their kin work and likewise, the relationship between kin work, family and nation state (Anthias and Yuval-Davis, 1992).

\section{Kin work and enacting citizenship through intergenerational relationships}

Migrant mothers face the challenge of balancing their kin work within the family alongside their desire to invest time and energy in themselves, in this case, through learning English. In the interventions in the forum theatre scene, participants rehearsed arguments and strategies for claiming this space and right to care for themselves visà-vis family members' demands to focus their care on their husbands and children. 
The challenges around parenting migrant children greatly concerned the mothers. Other studies have also investigated this issue. For example, Ryan and Vacchelli's (2013) study explored the use of religious and cultural repertoire with Muslim mothers to parent in a new migratory environment. These repertoires entailed the migrant mothers utilising 'the strong religious values' of Islam to assert parental authority within their family and community spheres, and to encourage their children to conform to parental expectations of religious norms. Yet they also utilised their religion as a cultural resource to negotiate cultural shifts needed to live in Western society, to mediate for their children the policing and surveillance of community members, and also to challenge what they saw as gender inequality that arose out of particular cultural practices.

Our study also similarly explored the use of cultural resources with migrant mothers in navigating parenting relationships. Through the participatory theatre scene performed we are able to deepen analysis by demonstrating the migrant mothers' embodied labour in constructing and negotiating the various layers and strategies of belonging. This aspect of the mothers' kin work, which also operated at the public/private boundary, was explored through the mother-daughter relationship. The scene, introduced by the facilitator, showed the 'mother' and 'daughter' in a migrant community centre (see www.open.ac.uk/socialsciences/migrant-mothers/ participatory-theatre/). It highlighted the issue of belonging to neighbourhood and community spaces. Through the scene we explored the various ways migrant mothers and their daughters encounter different relationships in their community setting. They may also view the community spaces differently as a result of intergenerational divisions.

Although the scene was introduced by the theatre facilitator, the participants quickly took ownership of the scene and developed it by giving it their own experiences and meanings. The scene decided on was as follows: the daughter feels bored and wants to leave as quickly as possible. The mother wants the daughter to take part in an event at the community centre and tries to persuade her to stay. However, both are confronted by criticism from other community members at the community centre. During the scene, the 'community members' comment on the daughter's clothes being 'too tight. They criticise her for not speaking 'our' language and for behaving in a 'rude' manner towards the mother. The scene culminates in the reproach by the community members that the daughter does not respect 'the culture' and that the mother failed to raise the daughter properly. Our analysis suggests that underpinning this concern of the mother for her daughter to remain is the fear of moral judgement from community members. The dominant policy rhetoric of surveillance and judgements around 'good mothering' is central to this narrative. However, rather than emanating from the state, in this instance it is the ethnic community that articulates a normative vision of good mothering.

While the mother is aware of this cultural narrative of 'good mothering', she is at the same time in the scene demonstrating a protectiveness of her daughter from the critical community members. During the various interventions into this scene, various participants took the role of mother to engage in differing strategies to try and persuade her daughter to remain at the community centre. This included, for example, bribery and incentives (for example, the purchase of mobile phone credit or even a new mobile phone), establishing time boundaries for the daughter to remain at the centre, for example, one hour maximum, or explaining to the daughter why it 
matters to the mother to be part of the ethnic community. Other strategies included the mother establishing relationships with the daughter's peers at the centre to motivate her to feel more at ease and therefore engage with her co-ethnics at the centre.

In theatre performance the use of props can provide a central focus to the dramatic constructions of narratives (Kaptani, 2011). During the mother-daughter scene the mobile phone was used as the main prop. It simultaneously acted as a form of protection, as a tool for bribery and as a site for negotiation. For instance, with regards to offering protection, it was used as a 'prop' by the daughter to create a barrier against the criticism directed towards her. During scenes she would take out her phone and start speaking into it or texting, which effectively prevented her from talking to others, while also providing a useful distraction. The mobile phone similarly acted as a tool for bribery. In this context, the mobile phone as a prop is enacted in quite an instrumental and strategic way: to entice the daughter to remain at the community setting by incentivising her to get a new phone or related apps. Finally, the phone operated as a site of negotiation between the mother and daughter. It provided an important prop for the mother, acting as a way for her to engage with the daughter by entering her space, bringing mother and daughter together. The phone in this context provided a means through which private intimate and emotional kin work are performed in public spaces. It provided a way for the mother and daughter to enter into dialogue and negotiation with each other.

During the forum theatre workshop sessions the migrant mothers reflected on the possibilities to positively intervene in scenes to change the course of action. They especially valued the way the theatre scene could be used as tool in their kin work to foster intergenerational exchange and learning between the mothers and their children:

'People give you different ideas: some gave choices to the teenager, others tried to calm them down and said "Don't worry we'll sort it out", some gave money. I now got ideas about how to challenge [the children's behaviour]. When you have young children, somehow you don't understand it. Normally our people who come from back home and their children grew up here, it is different, but at least we find here how to challenge our children.' (Natasza, Somali Muslim mother) ${ }^{3}$

Intergenerational exchange and learning, as a form of kin work, was regarded as a reciprocal process, with both mother and daughter learning from each other. Reflecting on her own mothering experience, Judyta reflects on how her daughter has encouraged her to be more tolerant and accepting of other people's cultures and multicultural values. But it was her participation in the workshops that allowed her to reflect and gain further understanding of ethnic and cultural differences

'[My daughter] is so accepting and now I am accepting of all cultures. And maybe from being [at the workshops], I know things from other cultures and their behaviour or how Muslims are behaving or how anyone is behaving. That's why I became more accepting and I understand them and it's great.'

The scene prompted the mothers to reflect on the way their children did not always understand the struggles and hardships they, as mothers, go through as low-status migrants to provide for their family. At the same time, the interventions empowered 
the mothers to make sense of generational and cultural tensions, while also valuing the importance of their own economic contribution in sustaining these intergenerational relationships.

The scene brings into sharp focus the way in which these mothers are re-framing notions of citizenship. The mothers' contribution to the cultural production of their children denotes a citizenship practice (Erel, 2011). Within this context, then, the 'kin work' that goes into cultural production is regarded as an investment in their children and family's future. First, the mothers are providing a counter-narrative to normative and hegemonic constructions of citizenship where migrant mothers are typically portrayed as endangering the social cohesion of citizenry and their perceived unwillingness to integrate or understand other cultures. The above quotation reflecting on mothers' experiences during the workshops challenges such a viewpoint. The mothers are engaging with social cohesion by learning about and embracing other migrant and minority ethnic cultures, and then sharing this with other family members. Second, the mothers' interaction and participation with other women from differing ethnic and racial backgrounds also encourages them to re-work understandings of their own cultural and ethnic heritage. This can result in mothers contesting homogenised and dominant notions of ethnic identity, as suggested by Erel's (2013) earlier work on the relationship between practices of mothering and questions of reproduction of citizenship.

Similarly, the kin work that goes into sustaining intergenerational relationships is an important element of the cultural production and reproduction of citizenship (Erel et al, 2018). During the mother-daughter scene, the participants reflected on how the differing parenting skills performed here could be used to build relationships with their children, particularly as they progressed through teenage years into adulthood. What was very apparent in their constructions of motherhood was the enduring nature of the mother-child bond, in ways that did not exist when describing other intimate relationships, as highlighted by Gamila, a South Asian Muslim mother, below:

'The children never finish but [spousal] relationships if they are broken they can finish, but with the children can never finish that's why I want to work on the relationship with children. You will always be a mother.'

This scene in the community centre also highlighted that the migrant mothers' relationships with other members of the ethnic community cannot be assumed to be supportive. On the contrary, migrant mothers can be called on to conform to ethnically specific ideals of good mothering. Migrant mothers can at times feel caught between their children's desires and the normative demands of 'good mothering' in specific ethnic community settings. The interventions the participants practiced in the scenes were also designed to improve communication and understanding with their children as well as mediating between their children and other community members. This finding is in contrast with public views of migrant mothers as strongly invested in bringing up their children as part of an ethnic community, while ignoring their children's desire to be part of wider British society (Ramji, 2007). 


\section{Conclusion}

This article explores how migrant mothering kin work challenges private/public boundaries, giving rise to new conceptions and practices of citizenship. The mothers' kin work enables them to enact a form of citizenship that takes into account the mothers' social, cultural and economic contribution to British society. It disrupts the dominant narratives and the moral of public debates that emphasise and decide what is means to be a 'good citizen', and who is included or excluded from this category.

The significance of the embodied aspect of citizenship became particularly clear in the ways in which they had to balance the conflicting desires and demands of kin work. The concept of kin work is central in highlighting how migrant mothers' work of caring for their families enables them to engage with wider society, for example, through education and work. Yet, contrary to hegemonic presentations of migrant mothers' embodied citizenship as fixed to the role of victim, the study showed how they engaged with a range of strategies of challenging their oppression along gender, racialised and classed power relations. The study found that migrant women's work of creating a form of belonging within the family and the community is an aspect of creating new understandings of citizenship beyond ethnic boundaries.

Participatory action research approaches of participatory theatre are integral to understanding how migrant mothers negotiate and contest motherhood, as well as citizenship discourses. Utilising Boal's techniques of forum theatre in the workshops captured the complex and nuanced ways in which these women embody citizenship through their kin work in the public as well as private domain. We also developed further insight into the more practical day-to-day examples of kin work that represented acts of embodied citizenship in their everyday lives. By sharing their experiences to make claims, we revealed these mothers' situated position as claimsmaking subjects, who are enacting citizenship.

Participatory theatre - specifically forum and Playback - operated as a successful intervention tool with the mothers because it enabled them to look on everyday life, raising awareness of collective and shared experiences of common social problems in order to offer a space to rehearse alternative courses of action. It legitimated the knowledge of these mothers, recognising and valuing the importance of their reproductive labour and contributions to the family household and British economy. Such analysis is important because their subordinate location in society, at the juncture of their gender, racialised and migrant status, makes them especially vulnerable in British society, where their contribution to the family and economy is not always recognised or valued within mainstream public and policy debates.

\footnotetext{
Notes

${ }^{1}$ Corresponding author.

${ }^{2}$ For details of a related and follow-on project,'Participatory arts and social action research', with Professor Maggie O'Neill, University of York, and funded by the Economic and Social Research Council (ESRC) and National Centre for Research Methods, please visit http://fass.open.ac.uk/research/projects/pasar

${ }^{3}$ All names have been anonymised
} 


\section{Acknowledgements}

We would like to thank Ronit Meranda, the filmmaker on the project, the women who participated in the project, and the anonymous referees for their valuable insights and comments on earlier drafts of the article.

\section{References}

Afshar, H, 2012, Secularism, racism and the contemporary politics of belonging: Muslim women in the UK, Secularism, Racism and the Politics of Belonging 33, 3, 165-79

Alber, E, Drotbohm, D, 2016 Anthropological perspectives on care: Work, kinship, and the life-course, London: Springer

Amigó, M, 2012, Liminal but competent: Latin American migrant children and school in Australia, Child Studies in Diverse Contexts, 2,1, 61-75

Anthias, F,Yuval-Davis, N, 1992, Racialized boundaries: Race, nation, gender, colour and class and the anti-racist struggle, London and New York: Routledge

Aspinall, P, Chinoyua, M, 2016, eds, The African diaspora population in Britain: Migrant identities and experiences, London: Springer

Bacchi, C, Beasley, C, 2002, Citizen bodies: Is embodied citizenship a contradiction in terms?, Critical Social Policy 22, 2, 324-52

Boal, A, 1979, Theatre of the oppressed, London: Pluto

Baldassar, L, Merla, L, 2013, Transnational families, migration and the circulation of care: Understanding mobility and absence in family life, London: Routledge

Bassel, L, Akwugo, E, 2017, The politics of survival: Minority women, activism and austerity in France and Britain, Bristol: Policy Press

Casey, L, Dame, 2016, The Casey Review: A review into opportunity and integration, London: Department for Communities and Local Government, www.gov.uk/government/ publications/the-casey-review-a-review-into-opportunity-and-integration

di Leonardo, M, 1984, The varieties of ethnic experience: Kinship, class and gender among California Italian-Americans, New York: Cornell University Press

di Leonardo, M, 1992, The female world of Christmas and holidays, www.anthropology. northwestern.edu/documents/people/TheFemaleWorldofCards.pdf

Denzin, N, K, Lincoln,YS, 2005, The SAGE Handbook of Qualitative Research, London: Sage

Diehl, C, Koenig, M, Ruckdeschel, M, 2009, Religiosity and gender equality: Comparing natives and Muslim migrants in Germany, Ethnic and Racial Studies $32,2,278-301$

Dominelli, L, 2006, Women and community action, Bristol: Policy Press

Dossa, P, Coe, C, 2016, Transnational aging and reconfigurations of kin work, New Brunswick, NJ: Rutgers University Press

Doucet,A, 2009, Gender equality and gender differences: Parenting, habitus, and embodiment (The 2008 Porter Lecture), www.andreadoucet.com/wp-content/uploads/2011/05/ Gender-Equality-and-Gender-Differences.pdf

Dustin, M, Phillips, A, 2008, Whose agenda is it?, Abuses of women and abuses of 'culture' in Britain, Ethnicities 8, 3, 405-24

Erel, U, 2011, Reframing migrant mothers as citizens, Citizenship Studies, 15, 6-7, 695-709

Erel, U, 2013, Kurdish migrant mothers in London enacting citizenship, Citizenship Studies 17, 8, 970-84 
Erel, U, Reynolds, T, 2014, Black feminist theory for participatory theatre with migrant mothers, Feminist Review Special Issue on Black British Feminism 108, 106-11

Erel, U, Reynolds, T, Kaptani, E, 2017a, Participatory theatre for transformative social research, Qualitative Research 17, 3, 302-12

Erel, U, Reynolds, T, Kaptani, E, 2018, Migrant mothers' creative interventions into racialized citizenship, Ethnic and Racial Studies 41, 1, 55-72

Erel, U, O’Neill, M, Reynolds, T, Kaptani, E, 2017b, Crisis upon crisis: Migrant families with no recourse to public funds, Discover Society, 44, https://discoversociety. org/2017/05/02/crisis-upon-crisis-migrant-families-with-no-recourse-to-publicfunds/

Fox, J, 1994, Acts of service: spontaneity, commitment, tradition in the nonscripted theatre, New Paltz, New York: Tusitala Publishing

Gedalof, I, 2009, Birth, belonging and migrant mothers: Narratives of reproduction in feminist migration studies, Feminist Review 93, 81-100

Hill Collins, P, 1990, Black feminist thought: Knowledge, consciousness, and the politics of empowerment, Boston, MA: Unwin Hyman

Hill Collins, P, 1994, Shifting the center: Race, class, and feminist theorizing about motherhood, in E Nakano Glenn, G Chang, L Forcey, eds, Mothering: Ideology, experience and agency, New York: Routledge, 45-65

Isin, E, 2008, Theorizing acts of citizenship, in E F Isin, G M Nielsen, eds, Acts of citizenship, London: Palgrave Macmillan, 15-43.

Joppke, C, 2009, Veil: Mirror of identity, Cambridge: Polity Press

Kaptani, E, 2011, Embodied methods and acts of power, Workshop Presentation at Open University, 23 June

Kaptani, E, forthcoming, Participatory theatre in research: A collaborative practice among social researchers and art practitioners

Kaptani, E, Yuval-Davis, N, 2008, Participatory theatre as a research methodology: Identity, performance and social action among refugees, Sociological Research Online, 13 (5): 2 http://www.socresonline.org.uk/13/5/2.html [last accessed 23 April 2018]

Kershaw, P, 2010, Caregiving for identity is political: Implications for citizenship theory, Citizenship Studies 14, 4, 395-410

Kofman, E, 2013, Gendered labour migrations in Europe and emblematic migratory figures, Journal of Ethnic and Migration Studies 39, 4, 579-600

Kofman, E, Raghuram, P, 2015, Gendered migrations and global social reproduction, London: Palgrave

Lewis, G, 2000, 'Race', gender, social welfare: Encounters in a postcolonial society, Cambridge: Polity Press

Lewis, G, 2004, Citizenship: Personal lives and social policy, Bristol: Policy Press in Association with Open University

Lister, R, 2003, Citizenship: Feminist perspectives, London: Palgrave MacmillanLister, R, 2008, Inclusive citizenship: Realising the potential, in EF Isin, P Nyers, BS Turner, eds, Citizenship between past and future, London, Routledge, 48-60

Lonergan, G, 2015, Migrant women and social reproduction under austerity, Feminist Review 109, 124-45

Lutz, H, 2010, Gender in the migratory process, Ethnic and Migration Studies, 36,10, 1647-63

Lutz, H, 2016, ed, Migration and domestic work: A European perspective on a global theme, New York: Routledge 
Marshall,TH, 1953, Citizenship and social class:And other essays, Cambridge: Cambridge University Press

Mirza, H, Reay, D, 2000, Spaces and places of educational desire: Rethinking Black supplementary schools as a new social movement, Sociology 34, 3, 521-44

Nandi, A, Platt, L, 2015, Patterns of minority and majority identification in a multicultural society, Ethnic and Racial Studies 38, 15, 2615-34

Okolosie, L, Harker, J, Green, L, Dabiri, E, 2015, It is time to ditch the term 'black Asian and minority ethnic (BAME)', The Guardian, 22 May, www.theguardian. com/commentisfree/2015/may/22/black-asian-minority-ethnic-bame-bmetrevor-phillips-racial-minorities

O'Neill, M, 2017, Walking, well-being and community: Racialized mothers building cultural citizenship using participatory arts and participatory action research, Ethnic and Racial Studies

O’Neill, M, Hubbard, P, 2010, Walking, sensing, belonging: Ethno-mimesis as performative praxis, Visual Studies 25, 1, 46-58

O’Neill, M, Woods, P, Webster, M, 2004, New arrivals, participatory action research, imagined communities and social justice, Journal of Social Justice 32, 1, 75-89

Pakulski, J, 1999, Cultural citizenship, Citizenship Studies, 1, 1, 73-86

Phoenix, A, Pattynama, P, 2006, Editorial: Intersectionality, European Journal of Women Studies, 13, 3, 187-92

Povinelli, E, 2006, The empire of love: Toward a theory of intimacy, genealogy and carnality, Durham, NC and London: Duke University Press

Ramji, H, 2007, Dynamics of religion and gender among young British Muslims, Sociology 41, 6, 1171-89

Redclift, V, 2014, New racisms, new racial subjects?: The neoliberal moment and the racial landscape of contemporary Britain, Ethnic and Racial Studies, 37, 4, 577-88

Reynolds, T, 2003, Black to the community: Black community parenting in Britain, Journal of Community, Work and Family 6, 1, 29-41

Reynolds, T, 2005, Caribbean mothering: Identity and childrearing in the UK, London: Tufnell Press

Reynolds, T, Erel, U, 2016, Migrant Mothers: creative interventions into citizenship, Open Democracy, 22 January 2016 https://www.opendemocracy.net/traceyreynolds-umut-erel/migrant-mothers-creative-interventions-into-citizenship [last accessed 20 April 2018]

Reynolds, T, Zontini, E, 2014, Transnational families: Migrant youths 'doing' families across proximities and distances, Families and Relationships Families Relationships and Societies 3, 2, 251-68

Ryan, L,Vacchelli, E, 2013, 'Mothering through Islam': Narratives of religious identity in London, Religion and Gender 3, 1, 90-107

Stack, C, 1981, All our kin: Strategies for survival in the black community, New York: Basic Books

Stack, C, Burton, L, 1994, Kinscripts: Reflections on family, generation and culture, in E Nakano Glenn, G Chang, L Forcey, eds, Mothering: Ideology, experience and agency, New York: Routledge, pp 198-213

Sudbury, J, 1998, Other kinds of dreams: Black women's organisations and the politics of transformation, London, Routledge

Walby, S, 1994, Is citizenship gendered?, Sociology 28, 2, 379-95 
Yuval-Davis, N, 2006, Intersectionality and feminist politics, European Journal of Women Studies, 13, 3, 193-209

Yuval-Davis, N, 2011, The politics of belonging: Intersectional contestations, London: Sage

Zontini, E, 2004, Immigrant women in Barcelona, Journal of Ethnic and Migration Studies 30, 6, 1113-44 